\title{
VALIDATING THE FRENCH HYDROMETEOROLOGICAL REANALYSIS (FYRE) WITH DOCUMENTARY EVIDENCE
}

Jean-Philippe VIDAL ${ }^{1}$,

Alexandre DEVERS ${ }^{1}$, Claire LAUVERNET ${ }^{1}$, Olivier VANNIER ${ }^{2}$, Laurie CAILLOUET ${ }^{2}$, Eric SAUQUET ${ }^{1}$, Benjamin GRAFF$^{2}$,

${ }^{1}$ INRAE, UR RiverLy, Villeurbanne, France

${ }^{2} \mathrm{CNR}$ (Compagnie Nationale du Rhône), Lyon, France

EGU2020: Sharing Geoscience Online 4-8 May 2020 


\section{Validating FYRE Hydro with documentary evidence}

Lack of historical streamflow observations 


\section{Lack of historical observations}

Number of streamflow stations in France

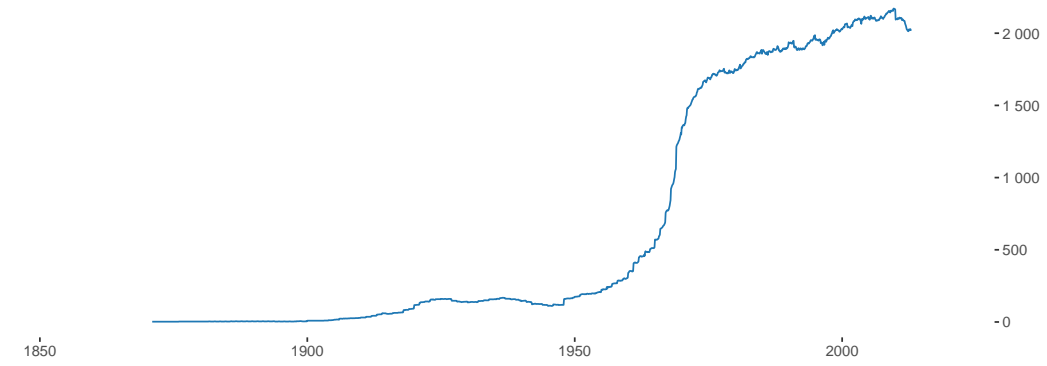

Lack of historical data in current databases for assessing local to countrywide hydrological variations 


\section{Validating FYRE Hydro with documentary evidence}

\section{Lack of historical streamflow observations}

FYRE Hydro

Validation with documentary evidence

(c) (1) 


\section{FYRE Hydro}

French Hydrometerological REanalysis - Hydrology

$\rightarrow$ Global atmospheric circulation 20CRv2 (1871-2012) 


\section{FYRE Hydro}

French Hydrometerological REanalysis - Hydrology

$\rightarrow$ Global atmospheric circulation 20CRv2 (1871-2012)

1. Statistical climate downscaling

$\rightarrow$ Meteorological reconstruction SCOPE Climate 


\section{FYRE Hydro}

French Hydrometerological REanalysis - Hydrology

$\rightarrow$ Global atmospheric circulation 20CRv2 (1871-2012)

1. Statistical climate downscaling

$\rightarrow$ Meteorological reconstruction SCOPE Climate

2. Assimilation of historical surface weather observations

$\rightarrow$ Meteorological surface reanalysis FYRE Climate 


\section{FYRE Hydro}

French Hydrometerological REanalysis - Hydrology

$\rightarrow$ Global atmospheric circulation 20CRv2 (1871-2012)

1. Statistical climate downscaling

$\rightarrow$ Meteorological reconstruction SCOPE Climate

2. Assimilation of historical surface weather observations

$\rightarrow$ Meteorological surface reanalysis FYRE Climate

3. Hydrological modelling with model uncertainty

$\rightarrow$ Hydrological reconstruction HYDREM 


\section{FYRE Hydro}

French Hydrometerological REanalysis - Hydrology

$\rightarrow$ Global atmospheric circulation 20CRv2 (1871-2012)

1. Statistical climate downscaling

$\rightarrow$ Meteorological reconstruction SCOPE Climate

2. Assimilation of historical surface weather observations

$\rightarrow$ Meteorological surface reanalysis FYRE Climate

3. Hydrological modelling with model uncertainty

$\rightarrow$ Hydrological reconstruction HYDREM

4. Assimilation of historical streamflow observations

$\rightarrow$ Hydrological reanalysis FYRE Hydro

Daily streamflow

661 near-natural catchments

25-members ensemble time series

1871-2012 


\section{Validating FYRE Hydro with documentary evidence}

\section{Lack of historical streamflow observations}

FYRE Hydro

Validation with documentary evidence 


\section{Validation with documentary evidence}

Target features

Low flows

Various spatial scales: small catchment to country-wide

Various temporal scales: daily to multi-decadal

Documentary evidence

Rather unconventional documents

Letter (1877)

Poem (1906)

Photograph (1942) 


\section{Validating FYRE Hydro with documentary evidence}

\section{Lack of historical streamflow observations}

FYRE Hydro

Validation with documentary evidence Letter 


\section{Letter: The intake of discord - 1877}

The Borne catchment (Borne may be translated as "boundary")

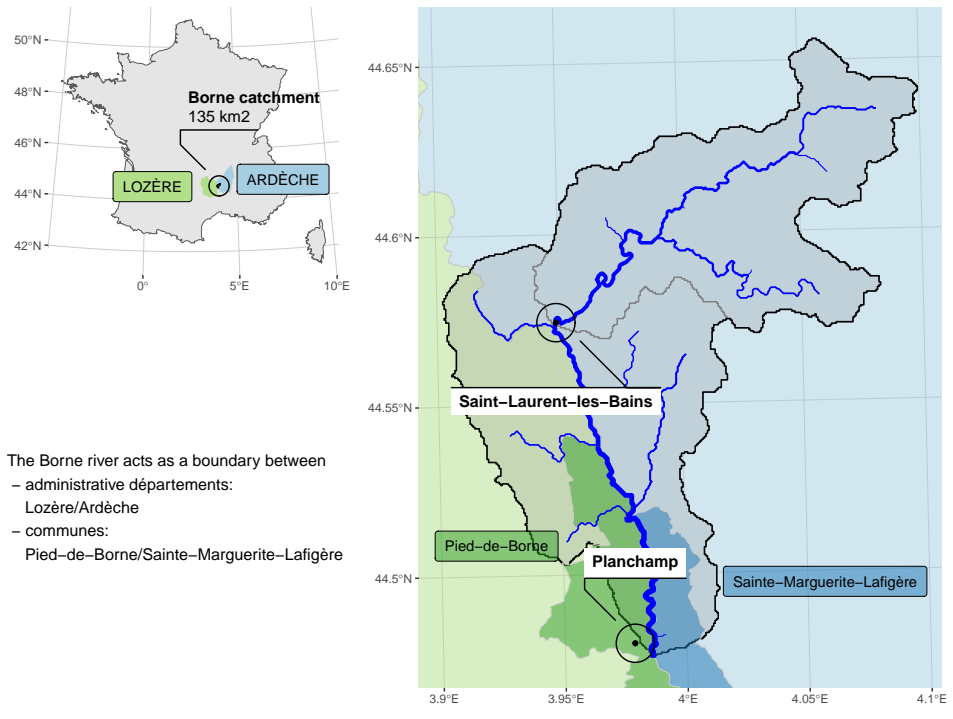




\section{Letter: The intake of discord - 1877}

Numerous water intakes on both sides for irrigation

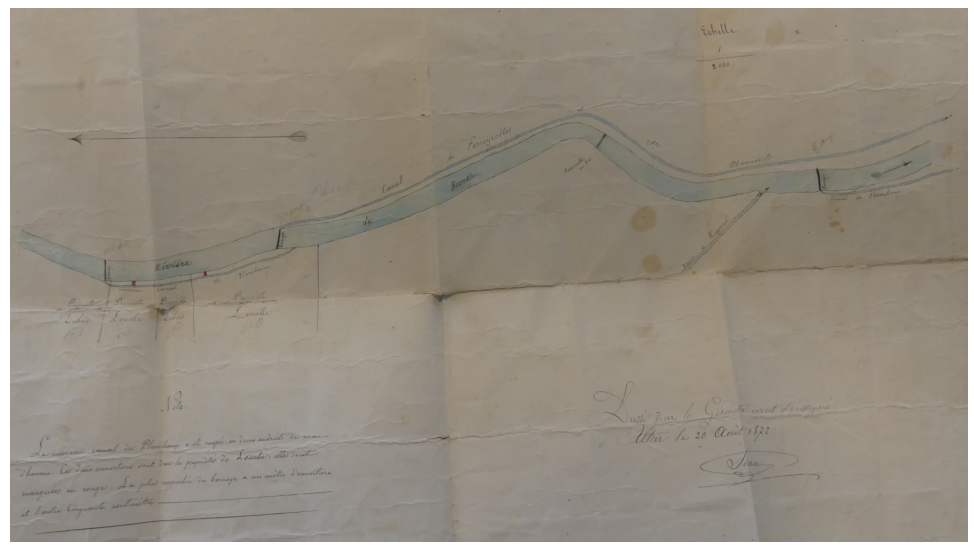

Map of water intakes on Ardèche (up) and Lozère (down) sides, dressed in 1872. Photograph Maël CRÉPY. 


\section{Letter: The intake of discord - 1877}

\section{The dwellers' letter}

\section{Original manuscript version transcribed by Maël CRÉPY}

\section{«Planchamp 5 août 1877 :}

Monsieur le Préfet,

A lé réception de vorte [sic] aretté [sic] du 5 juillet consernan [sic] le partage des eau [sic] de la Borne, les interesés [sic] de la commune de Saint Jean Chazorne et ceux de Planchamp se son [sic] empréssé [sic] de [illisible] vos ordres. Mas [sic] le cotté de l'ardèche ils non [sic] rien fait pour sela [sic] au contraire ils dises [sic] qu'il [sic] ne veule [sic] pas le faire.

Depuis un mois nous sommes privés des eaux, et toutes nos récoltes perisses [sic] par la privations de ses eau [sic].

Nous vous prion [sic] Monsieur le Préfet de faire exequter [sic] vos ordres par l'ardèche, et nous faire connaitre seque [sic] nous aurons à faire en cas ou [sic] ils ne les exequte [sic] pas prontemen [sic].

Dans l'espoir que vous voudrer [sic] bien faire droit à notre juste réclamation nous avons l'honneur de nous dire de Monsieur le Préfet les très humbles et très dévoue sujet [sic].

[4 signatures] "

\section{Corrected and translated version}

"Planchamp 5 August 1877 :

Mr. Prefect,

Upon receipt of your decree of July 5 concerning the sharing of the waters of the Borne, the interested parties of the commune of Saint Jean Chazorne and those of Planchamp hastened to [unreadable] your orders. But on the Ardèche side they did nothing for that, on the contrary they say they don't want to do it.

For a month now, we have been deprived of its waters, and all our crops are perishing because of the deprivation of its waters.

We ask you, Mr. Prefect, to have your orders executed by the Ardèche, and to let us know what we will have to do if they do not execute them promptly.

In the hope that you will be willing to accept our just complaint, we have the honour to say of the Prefect the very humble and devoted subjects.

[4 signatures]" 


\section{Letter: The intake of discord - 1877}

FYRE Hydro reconstructed natural streamflow on the upper catchment

The Borne river @ Saint-Laurent-les-Bains

Reconstructed natural streamflow in 1877 compared to 1871-1900 regime, and zoom on summer
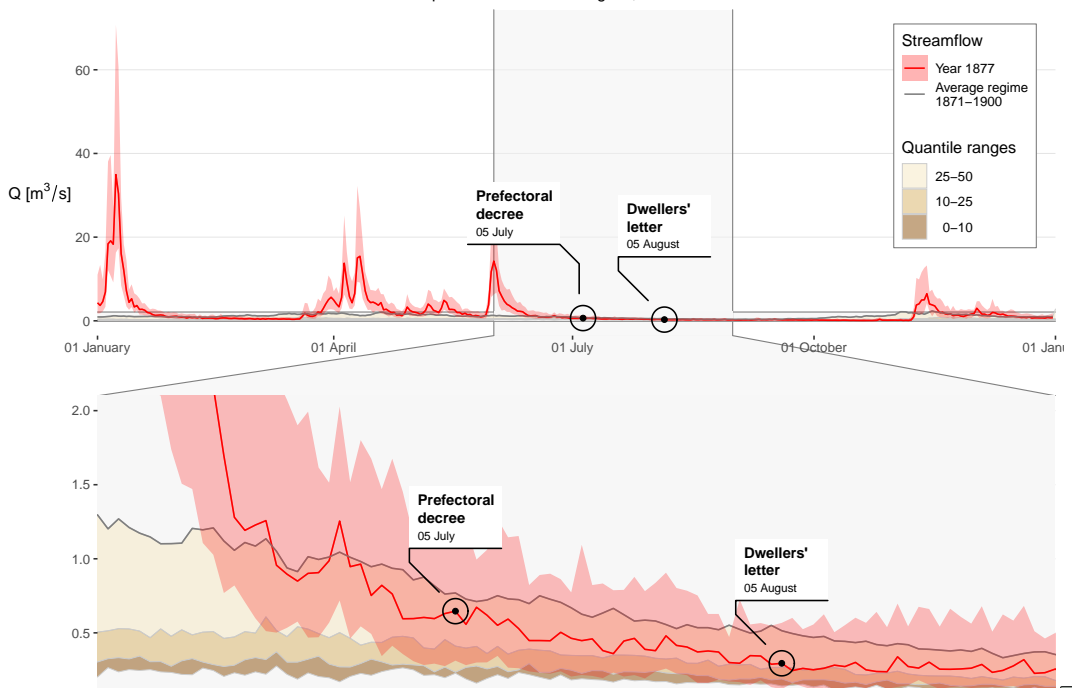

$0.0-$
01 July

15 July

01 August

15 Aúgust 


\section{Letter: The intake of discord - 1877}

Validation summary

Fact checking

"For a month now, we have been deprived of its waters": upstream natural water resources under long-term average 1 month before the letter is sent Water resources amount down to quantile 0.25 at the time of letter writing: low but not exceptional

Anthropogenic water shortage as suggested by dwellers

Conclusion

FYRE Hydro is able to reconstruct the timing of low flows on very small catchments where and when no streamflow data were available 


\section{Validating FYRE Hydro with documentary evidence}

\section{Lack of historical streamflow observations}

FYRE Hydro

Validation with documentary evidence

Poem

Photograph 


\section{Poem: "Obsession for water" - 1906}

Le Courrier Français, weekly newspaper

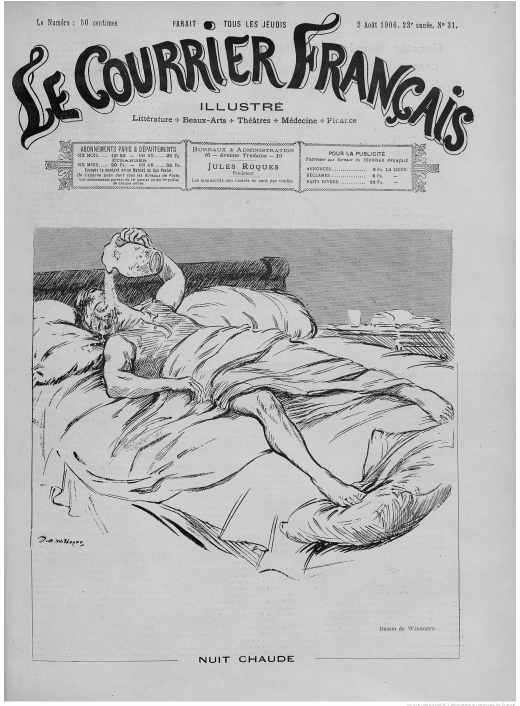

Newspaper's cover for 2 August 1906 


\section{Poem: "Obsession for water" - 1906}

Le Courrier Français, section “Gazette rimée”: "Obsession de l’eau »

\section{Original text}

"Chaque année, à la même époque,

Quand sous la chaleur on suffoque,

C'est le même cri dans Paris :

Ah! mon Dieu, si l'eau continue

À ne pas tomber de la nue,

Nous allons tous être cuits, frits.

Que sur quelque fleuve baroque,

Le Mançanarès, l'Orénoque...

$\mathrm{Ne}$ vient pas nous ravitailler,

Comment pousserons nos fleurs, voire

Qu'est-ce donc qu'il nous faudra boire?

Avec quoi nous débarbouiller?

Nos puits sont morts et nos citernes

Ne furent jamais aussi ternes.

Nous avons épuisé la Dhuis,

Le lac Pigalle ainsi que l'Avre :

Et la sécheresse vous navre

De la Fontaine Médicis... »

\section{Tentative translation}

"Every year, at the same time of year, when under the heat we are suffocating, it is the same cry in Paris:

Oh my God, if the water keeps on not falling from the sky, we are all going to be cooked, fried.

That if some baroque river, the Mançanarès, the Orinoco... doesn't come to supply us, how will our flowers grow, or even what will we have to drink? What will we wash ourselves with?

Our wells are dead and our cisterns have never been so dull. We've exhausted the Dhuis, the Pigalle Lake and the Avre: And the drought is bothering you from the Médicis Fountain..." 


\section{Poem: "Obsession for water" - 1906}

Streamflow conditions in the Seine basin in August 1906 according to FYRE Hydro

August 1906

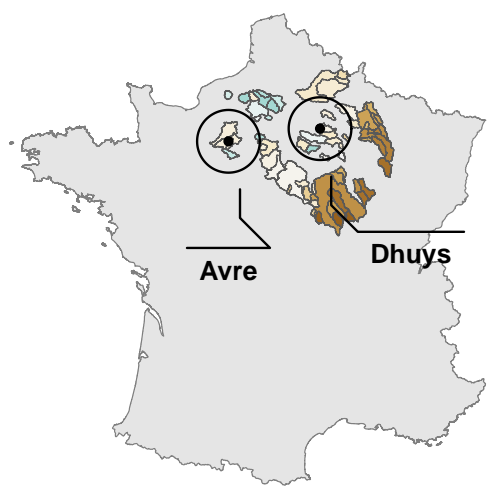

August-average flow duration curve 1871-1906

Maximum

Median
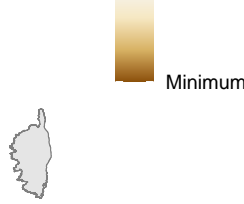

The Dhuys and Avre rivers serve as water intakes for aqueducts supplying Paris with water. They were at the time in a relatively dry state. 


\section{Poem: “Obsession for water" - 1906}

Le Courrier Français, section "Gazette rimée": «Obsession de l'eau »

\section{Original text}

"Chaque année, à la même époque,

Quand sous la chaleur on suffoque,

C'est le même cri dans Paris :

Ah ! mon Dieu, si l'eau continue

À ne pas tomber de la nue,

Nous allons tous être cuits, frits.

Que sur quelque fleuve baroque,

Le Mançanarès, l'Orénoque...

Ne vient pas nous ravitailler,

Comment pousserons nos fleurs, voire

Qu'est-ce donc qu'il nous faudra boire?

Avec quoi nous débarbouiller?

Nos puits sont morts et nos citernes

Ne furent jamais aussi ternes.

Nous avons épuisé la Dhuis,

Le lac Pigalle ainsi que l'Avre :

Et la sécheresse vous navre

De la Fontaine Médicis... »
Tentative translation

"Every year, at the same time of year, when under the heat we are suffocating, it is the same cry in Paris:

Oh my God, if the water keeps on not falling from the sky, we are all going to be cooked, fried.

That if some baroque river, the Mançanarès, the Orinoco... doesn't come to supply us, how will our flowers grow, or even what will we have to drink? What will we wash ourselves with?

Our wells are dead and our cisterns have never been so dull. We've exhausted the Dhuis, the Pigalle Lake and the Avre: And the drought is bothering you from the Médicis Fountain..." 


\section{Poem: "Obsession for water" - 1906}

Streamflow conditions in the Seine basin in August 1903-1906 according to FYRE Hydro

August 1903

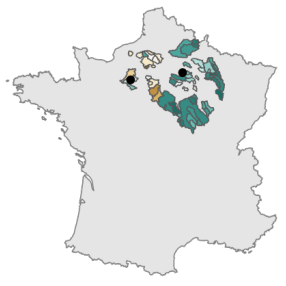

August 1905

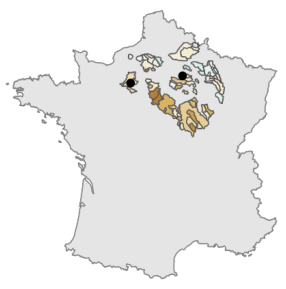

August 1904

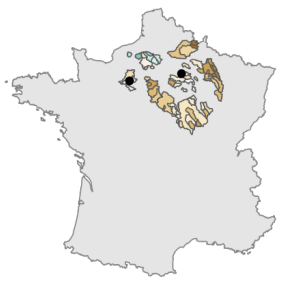

August 1906

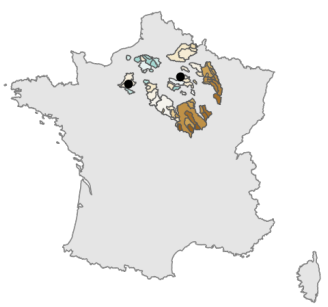

August-average

Flow duration curve 1871-1906

Maximum

Median

Minimum

3-4 years in a row with lower-than-normal August streamflow for the Seine basin. 


\section{Poem: "Obsession for water" - 1906}

Streamflow conditions in France in August 1903-1906 according to FYRE Hydro

August 1903

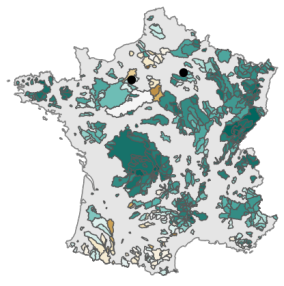

August 1905

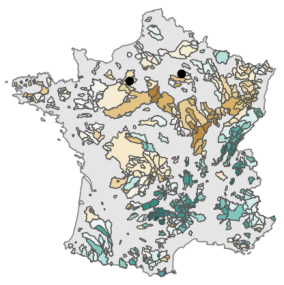

August 1904

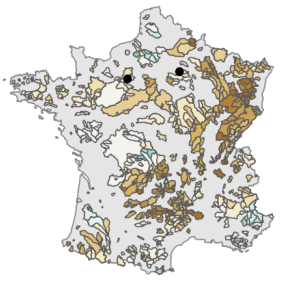

August 1906

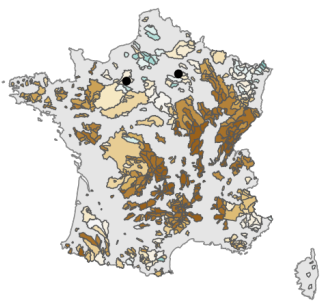

August-average

Flow duration curve 1871-1906

Maximum

Median

Minimum

One of the few basins in France with such recurring dry conditions. 


\section{Poem: “Obsession for water" - 1906}

Validation summary

Fact checking

"Every year, at the same time of year [...] We've exhausted the Dhuis [...] and the Avre". - 23 August 1906

Lower-than-normal 1906 August streamflow conditions over the Seine basin 3-4 years in a row width dry conditions

The Seine basin is one a the few ones in France with such August dry conditions over the past few years

Conclusion

FYRE Hydro is able to reconstruct multi-year recurring dry conditions and contrasts between large basins. 


\section{Validating FYRE Hydro with documentary evidence}

\section{Lack of historical streamflow observations}

FYRE Hydro

Validation with documentary evidence

Photograph

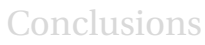

(c) (1) 


\section{Photograph: The Seine closure - 1942}

The Seine at Paris during low flows

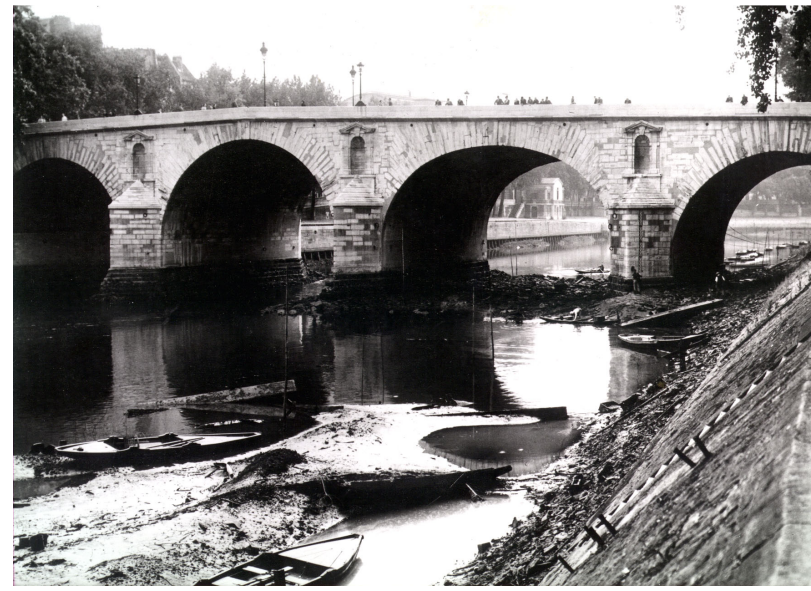

The Seine river at Marie bridge (Paris), 16 or 19 August 1942. (unknown photographer) 


\section{Photograph: The Seine closure - 1942}

The Seine at Paris during low flows

Summer low-flows in Paris

The photograph shows very low water levels in Paris

Possible closure of the Seine in Paris by closing upstream ship locks and opening downstream ones

Used by Nazis during WWII (and French officials after the war) to inspect bridge piers:

August 1942

July 1943

October 1944

September 1946

Natural conditions during closures

Operation only possible during very low-flow periods

Very dry 1940s in France 


\section{Photograph: The Seine closure - 1942}

\section{Multidecal streamflow variability in France according to FYRE Hydro}

Multidecadal streamflow variability over 661 near-natural catchments

Annual standardized anomalies with respect to 1973-2006 with a 20-year smoothing

$2-$

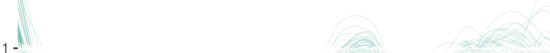

0 -

$-1$

$-1$

$-2-$

$18 \dot{8} 80$

1920

$19 \dot{6} 60$

2000

Black points identify 70 near-natural catchments in the Seine basin. 


\section{Photograph: The Seine closure - 1942}

Validation summary

\section{Fact checking}

\section{Low water levels in August 1906 in Paris}

Photograph testifies from natural streamflow low enough to perform Seine closures

Several examples of such dry conditions during the 1940s

Dry decade well identified in FYRE Hydro

Conclusion

FYRE Hydro is able to show multi-decadal variability and multi-year droughts over France. 


\section{Validating FYRE Hydro with documentary evidence}

\section{Lack of historical streamflow observations}

FYRE Hydro

Validation with documentary evidence

Conclusions 


\section{Conclusions}

Validating FYRE Hydro with documentary evidence

Developping an ensemble daily streamflow reanalysis covering 142 years for 661 near-natural catchments in France: FYRE Hydro

Validating the reanalysis on low-flow events at various temporal and spatial scales

Using unconventional historical evidence that show the high potential of hydrological information in documentary archives

Highlighting anthropogenic characteristics of low-flows during the Anthropocene 


\section{References}

Caillouet, L., Vidal, J.-P., Sauquet, E., Graff, B., and Soubeyroux, J.-M. (2019). SCOPE Climate: a 142-year daily highresolution ensemble meteorological reconstruction dataset over France. Earth System Science Data 11 (1), pages 241260. D OI: 10.5194/essd-11-241- 2019.

Compo, G. P., Whitaker, J. S., Sardeshmukh, P. D., Matsui, N., Allan, R. J., Yin, X., Gleason, B. E., Vose, R. S., Rutledge, G., Bessemoulin, P., Brönnimann, S., Brunet, M., Crouthamel, R. I., Grant, A. N., Groisman, P. Y., Jones, P. D., Kruk, M. C., Kruger, A. C., Marshall, G. J., Maugeri, M., Mok, H. Y., Nordli, Ø., Ross, T. F., Trigo, R. M., Wang, X. L., Woodruff, S. D., and Worley, S. J. (2011). The Twentieth Century Reanalysis Project. Quarterly Journal of the Royal Meteorological Society 137 (654), pages 1-28. D OI: 10.1002/qj. 776.

Delaigue, O., Génot, B., Lebecherel, L., Brigode, P., and Bourgin, P.-Y. (2020). Database of watershed-scale hydroclimatic observations in France.

Devers, A., Vidal, J.-P., Lauvernet, C., Graff, B., and Vannier, O. (2020). A framework for high-resolution meteorological surface reanalysis through offline data assimilation in an ensemble of downscaled reconstructions. Quarterly Journal of the Royal Meteorological Society 146 (726), pages 153-173. D O I: 10.1002/qj . 3663.

Devers, A. (2019). Vers une réanalyse hydrométéorologique à l'échelle de la France sur les 150 dernières années par assimilation de données dans des reconstructions ensemblistes (Towards a French hydrometeorological reanalysis over the last 150 years through data assimilation in ensemble reconstructions). $\mathrm{PhD}$ thesis. $\mathrm{PhD}$ thesis, Université Grenoble Alpes.

Van Loon, A. F., Gleeson, T., Clark, J., Van Dijk, A. I. J. M., Stahl, K., Hannaford, J., Di Baldassarre, G., Teuling, A. J., Tallaksen, L. M., Uijlenhoet, R., Hannah, D. M., Sheffield, J., Svoboda, M., Verbeiren, B., Wagener, T., Rangecroft, S., Wanders, N., and Van Lanen, H. A. J. (2016). Drought in the Anthropocene. Nature Geoscience 9 (2), pages 89-91. D O I: 10 . 1038/ ngeo2646.

Navratil, O., Jacob-Rousseau, N., Crépy, M., Doledec, S., Vidal, J.-P., and Sauquet, É. (2019). ArchPress - Apport des données d'ARCHives hydrologiques pour l'étude des PRESSions sur la ressource en eau et les milieux aquatiques dans les rivières cévenoles depuis la fin du XIX ${ }^{e}$ siècle. Final report - Action $\mathrm{n}^{\mathrm{O}} 52$ of the 2010 programme of the Agence de l'Eau Rhône Méditerranée Corse - ZABR research framework. Archéorient, EVS, Lehna, Irstea RiverLy. 114 pages.

Phliponeau, P. (1977). la Seine à sec. Paris aux cent villages 21, pages 11-13.

Vidal, J.-P. (2019). Écrire l'hydrologie de l'Anthropocène (Writing the hydrology of the Anthropocene). Mémoire d'Habilitation à Diriger des Recherches. Habilitation manuscript, Université Grenoble-Alpes. 184 pages. 

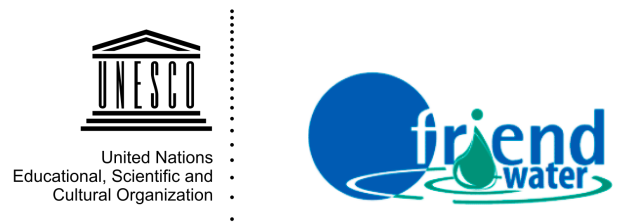

EURO-FRIEND Low flow and Drought group

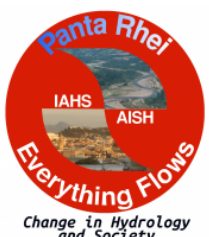

Working Group Drought in the Anthropocene

Thank you for your attention!

Contact: jean-philippe.vidal@inrae.fr 